\title{
EXTREME RAINFALLS AS A CAUSE OF URBAN FLASH FLOODS; A CASE STUDY OF THE ERBIL-KURDISTAN REGION OF IRAQ
}

\author{
Andam M. Mustafa ${ }^{\bowtie}$, Hadi H. Muhammed, Michal Szydłowski \\ Faculty of Civil and Environmental Engineering, Gdańsk University of Technology, Gdańsk 80-233
}

\begin{abstract}
\section{Aim of the study}

The current paper aims to give a detailed evaluation and analysis of some extreme rainfall events that happened in the last decade in terms of spatial and temporal rainfall distribution, intensity rate, and exceedance probability. Moreover, it examines the effects of each analysed aspect on the resulting flash floods in the studied area.
\end{abstract}

\begin{abstract}
Material and methods
In their glossary of meteorology, American Meteorology Society (AMS) subdivided rainfall intensity types into four groups (light, moderate, heavy, and violent). Also, for estimating the exceedance probability, lognormal distribution was applied as a statistical model of the precipitation probability distribution function.
\end{abstract}

\begin{abstract}
Results and conclusions
Out of six episodes, five of the analysed events were classified as heavy rainfall. However, the duration of those heavy rainfall events was not more than two hours. Four events of maximum daily rainfall (for a 39 -year dataset) were rated at $1-10 \%$ of exceedance probability. To conclude, the current study can be an initial step in modelling hydrological events in the studied area, and in the process of transforming precipitation into the outflows of urban basins in the future.
\end{abstract}

Keywords: climate change, urban flash floods, rainfall intensity, rainfall temporal distribution, rainfall probability distribution

\section{INTRODUCTION}

Rain is one of the essential sources of fresh water on Earth, provided through the lengthy hydrologic cycle; yet at the same time, it is a source of natural disasters, for instance, urban flash floods. If disasters such as these are not analysed, assessed, and taken into consideration, they may cause huge losses and damage to housing properties, roads, bridges, and industrial areas. Flooding is one of the most frequently occurring natural hazards globally (Kvočka et al., 2015). According to Opolot (2013) during flood and post-flood stages, during the period 2000-2008, in each year, about 99 million inhabitants worldwide were influenced by floods. Pluvial flooding due to extreme rainfall events in a limited time has increased worldwide. The causes vary from one country to another. The mainspring, however, is related to population growth and urban development, leading to increasing changes in land cover,

凶e-mail: andam.mustafa@pg.edu.pl 
and to climate change. Each of these aspects has its effect on a flooding event. If these aspects are not taken into consideration, the increase in population and urban development, which means an increase in surface runoff, eventually will cause a greater, significant loss in economic terms and in terms of social welfare. Moreover, climate change will play a crucial role in intensifying and accelerating the hydrologic cycle (Christensen and Christensen, 2007; Kundzewicz et al., 2008) and is predicted to result in an increased frequency of the occurrence and intensity of extreme rainfall events, which in turn is predicted to increase the extent and recurrence of future floods (Allan and Soden, 2008; Pall et al., 2011; Rojas et al., 2013). Veldhuis et al. (2011) and Ashley (2005) added another cause of flooding to the factors mentioned above, which is ageing infrastructure. Also, behavioural patterns, demographics, and other contextual factors, such as the timing and the day of the week the storm occurs, may have a particular effect on the type and magnitude of damage (Miceli et al., 2008). However, it is not only the infrastructure of developed cities but also the citizens that are vulnerable to the effects of extreme hydrologic events such as intense rainfalls or unexpected snow melts (Szydłowski et al., 2015).

Climate change remodelling in response to the increased risk of flooding has gained importance on the political agenda in some countries during recent years. Hence, climate change adaptation planning has occurred in some cities worldwide, in countries across different continents, as a consequence of the increase in the number of floods. One of the most massive storms hit the Danish capital, Copenhagen, on July 2, 2011. During this event, precipitation intensities higher than 2000-year return periods were recorded at the most critical locations (Arnbjerg-Nielsen et al., 2015). The city of Gdańsk in Poland was flooded on July 9, 2001 due to rainfall precipitation of about $123.5 \mathrm{~mm}$, which resulted in economic and social losses. The flood impacted more than 300 families were (damaged houses, loss of property), whereas basements of numerous houses and flats were flooded and required the water to be pumped out. More than 5000 inhabitants received special calamity status and the total flood damage to infrastructure in Gdańsk amounted to about $€ 40$ mil- lion (Majewski, 2016). Szpakowski and Szydłowski (2018) stated that the rainfall event which happened in Strzyża basin in Gdańsk, Poland, on July 12, 2016 was catastrophic because the total sum of rainfall over 16 hours was $150.8 \mathrm{~mm}$. According to the rainfall station of the Gdańsk University of Technology, this rainfall event was identified as one of the highest daily amounts in the northern part of Poland. In France, the number of extreme rainfall events also increased. The episode of June 15, 2010 was particularly intense. The maximum amount of rain recorded at the Meteo-France station of "Les Arcs-sur-Argens" reached $400 \mathrm{~mm}$ in 24 hours (including $330 \mathrm{~mm}$ in less than 10 hours) (Ruin et al., 2013). Flash flooding is a costly and deadly problem across the United States. In 2015, compared to any other weather-related hazard, flash flooding caused the most fatalities and cost the most dollars in damage (Smith and Rodriguez, 2017). In 2003, in the state of Kansas, USA, a total of $150-200 \mathrm{~mm}$ of precipitation fell during three hours in a basin with a catchment area of $5 \mathrm{~km}^{2}$. Consequently, six people died (Ávila et al., 2015).

In India, Guwahati in 2010, Delhi in 2010, 2009, 2003 and 2002, Jamshedpur in 2008, Kolkata in 2007, Surat in 2006, Mumbai in 2005, Chennai in 2004, Ahmedabad in 2001 and Hyderabad in 2000 were all affected by urban flash flooding during high-intensity rainfall events. These events indicate that an increasing trend in urban flood catastrophes has been observed since the beginning of the twenty-first century (Bisht et al., 2016). In the area of Seoul, the capital city of South Korea, an extreme rainfall event occurred in 2010, with the total amount of $259.2 \mathrm{~mm}$ in 24 hours, as well as a maximum intensity of $98.7 \mathrm{~mm} /$ hour, destroying 17,645 houses during the resulting urban flash flood (Joo et al., 2014).

Jeddah, the capital city of Saudi Arabia, experienced heavy rainfall in November 2009, which lasted for only three hours but caused massive flooding, resulting in loss of life and damage to infrastructure and property: over 113 fatalities, many people injured, and the destruction of more than 10,000 homes and industrial properties (Youssef et al., 2016). In Ikitelli, Istanbul, Turkey, a neighbouring country located in the north of the studied area, 20 people died and a commercial district was destroyed due to a flash flood in 2009 (Ávila et al., 2015). 
Erbil, a province situated in the north of Iraq, has suffered from urban flash floods since the 1930s. In recent decades, the number of floods due to heavy rainfall has increased. Erbil Centre district is situated in a flat or low elevated area compared to the east and northeast of the city, which occupy mountainous areas. Moreover, the flow directions are from the east and northeast to the west and southwest. Thus, Erbil Centre district is more prone to urban flash floods. This paper questions why accumulation of water in the streets, sewer system overflows and blockages, power outages in some areas, road damage and decreasing traffic flow have occurred after almost every rainfall. To the best of our knowledge, very few studies have been conducted on urban flash floods in Erbil. For this reason, the scientific significance of the results described in the article is high. The lack of such data so far precluded the possibility of conducting research in the field of hydrological modelling. Therefore, there is a need to study heavy rainfalls and flash floods frequently occurring in the city centre. The analysis of precipitation is one of the essential factors in hydrological modelling, especially in building hypothetical (synthetic) rainfall models. The time distribution model, exceedance probability, basin characteristics, basin geometry and other criteria are used as input data in the calculation of basin outflows. The current paper offers a detailed evaluation and analysis of some extreme rainfall events that happened over the last decade in terms of spatial and temporal rainfall distribution, intensity rate, and exceedance probability. Moreover, it examines the effects of each analysed aspect on the resulting flash floods in the studied area. So far, such studies have not been carried out; therefore, the results presented in this article constitute an innovative scientific contribution to the development of knowledge about hydrology of Iraq.

\section{MATERIAL AND METHODS}

\section{Study area}

Erbil (also known as Hawler) is the capital city of the Kurdistan Region in the north of Iraq. Erbil Province has a total area of $14,873.68 \mathrm{~km}^{2}$, while the Centre district of Erbil, which has been selected as the study area in this work, has an area of $1131.44 \mathrm{~km}^{2}$ (see: Fig. 1).
The population of Erbil governorate was 2,009,637 inhabitants in 2015 and of the Centre district was 930,389 in 2015 (KRSO, 2014). It lies approximately 350 kilometres (220 miles) from Baghdad, the capital of Iraq. Erbil Centre district is situated in a mostly flat area, while the northeast and east areas are predominantly mountainous, connecting Iraq to both Iran and Turkey. Furthermore, south of the city is a lowland territory; it is an agricultural zone inhabited by rural population. Hassan M. Hammed (2017) indicated that built up areas and bare soil increased in the central district of Erbil between 1984 and 2014 by $53.26 \%$ and $52.72 \%$ respectively. Conversely, vegetation and agricultural land decreased by $50.06 \%$ and $57.72 \%$ respectively. Concerning the sewer system, the city has a combined drainage system not including the grey water; instead, the latter is collected from the houses' cesspools and conveyed out of the city. Also, the system's outlet is connected to a river. In the last ten years, many intense rainfalls resulted in flash floods in this area. For example, according to Erbil meteorological station, the maximum rainfall was $71.8 \mathrm{~mm}$ during 24 hours on January 28, 2013; also: 67, 55.8, 51, 42.4 and $47.7 \mathrm{~mm}$ on April 22, 2011, December 31, 2015, January 27, 2014, March 28, 2016 and November 22, 2018, respectively.

\section{Meteorological data and situation}

The meteorological dataset for this study has been collected from three different sources; from 1980 to 1991 the dataset was obtained from the Climate Forecast System Reanalysis (CFSR) of the National Centre for Environmental Prediction. In that period, the studied area was an insecure region; the officials from meteorological stations were not able to record the weather dataset regularly. However, the dataset from the CFSR has previously been used by other researchers (Dile and Srinivasan, 2014; Fuka et al., 2014; Nanekely et al., 2016). The General Directorate of Meteorology and Seismology in Kurdistan region/Iraq (GDMS) provided the dataset from 1992 to 2018. The rainfall data were recorded daily and steadily by using a standard classic rain gauge inside Erbil. The remainder of the data has been obtained from the Directorate of Irrigation/Erbil and General Directorate of Agriculture/ Erbil. Both directorates have their automatic meteorological station inside the Centre district of Erbil. 
Mustafa, A.M., Muhammed, H.H., Szydłowski, M. (2019). Extreme rainfalls as a cause of urban flash floods; a case study of the Erbil-Kurdistan region of Iraq. Acta Sci. Pol., Formatio Circumiectus, 18 (3), 113-132. DOI: http://dx.doi.org/10.15576/ASP.FC/2019.18.3.113
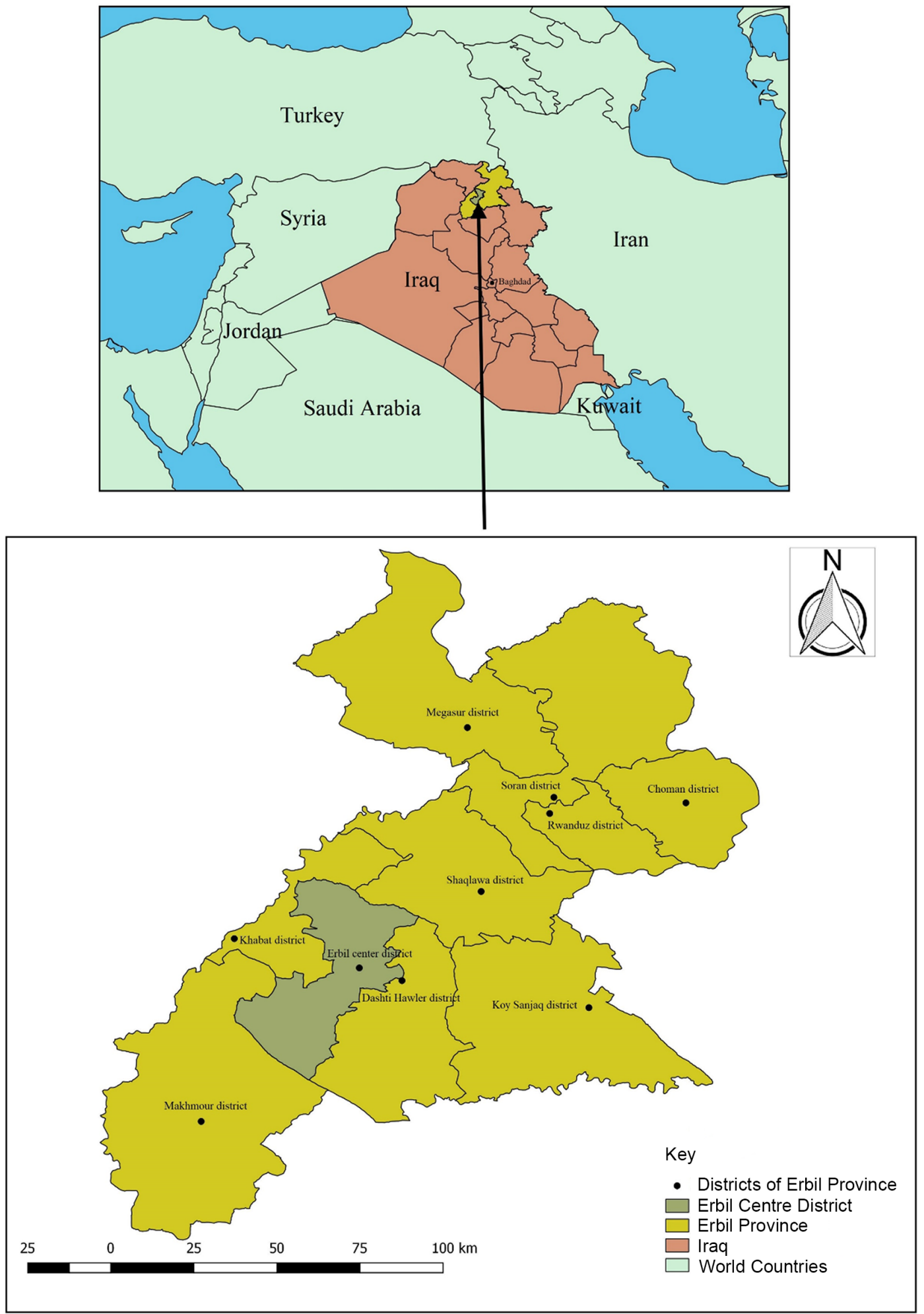

Fig. 1. Erbil Province and Centre district 
Mustafa,A.M., Muhammed, H.H., Szydłowski, M. (2019). Extreme rainfalls as a cause of urban flash floods; a case study of the Erbil-Kurdistan region of Iraq. Acta Sci. Pol., Formatio Circumiectus, 18 (3), 113-132. DOI: http://dx.doi.org/10.15576/ASP.FC/2019.18.3.113

Table 1 shows the meteorological stations in Erbil Province, whose data from different periods have been used for this study.

The Kurdistan region has a semi-arid continental climate and is characterised by hot and dry summers and cold and wet winters. The climate is affected by Iraq's geographical position between the subtropical aridity of the Arabian desert areas, and the subtropical humidity of the Persian Gulf. The summer lasts from June till the beginning of October, while the winter starts in December and ends in March. The mean temperature is between $6^{\circ} \mathrm{C}$ and $16^{\circ} \mathrm{C}$ in the winter season, but it ranges between $25^{\circ} \mathrm{C}$ and $40^{\circ} \mathrm{C}$ in the summer season. Generally, yearly water precipitation is concentrated between October and May. The maximum monthly rainfall occurs in January and December. Hassan M. Hameed (2013) indicated that due to the topography and elevation above sea level (ASL), Erbil Province's annual rainfall fluctuates. For example, in the north and northeast, with an average elevation of $3000 \mathrm{~m} \mathrm{ASL}$, annual rainfall reaches $1275 \mathrm{~mm}$, and other precipitations, such as snow, are also recorded; however, in the south and southwest of the city, which has an elevation between 166 and $400 \mathrm{~m} \mathrm{ASL}$, the maximum annual rainfall is $612 \mathrm{~mm}$ and the minimum is about $206 \mathrm{~mm}$.

Figure 2 shows the maximum daily rainfall in the Centre district of Erbil Province in 1980-2018. In the twentieth century, daily rainfall fluctuated between 20 and $80 \mathrm{~mm}$, and it is apparent that Erbil Centre dis-

Table 1. Meteorological stations in Erbil Province

\begin{tabular}{|c|c|c|c|c|c|c|}
\hline No. & Name of the station & Longitude E & Latitude $\mathbf{N}$ & $\begin{array}{l}\text { Period } \\
\text { (years) }\end{array}$ & $\begin{array}{c}\text { Elevation } \\
\text { (mASL) }\end{array}$ & Note \\
\hline 1 & Khabat Station & 43.65000 & 36.26610 & \multirow{2}{*}{$2001-2006$} & 252 & \multirow{16}{*}{$\begin{array}{c}\text { Located in } \\
\text { the target } \\
\text { area }\end{array}$} \\
\hline 2 & Qushtapa Station & 44.03190 & 36.00390 & & 398 & \\
\hline 3 & Irrigation Directorate/Erbil Station & 44.00942 & 36.16150 & 2008-2018 & 406 & \\
\hline 4 & $\begin{array}{l}\text { General Directorate of Agriculture/ } \\
\text { Erbil Station }\end{array}$ & 44.01452 & 36.17183 & 2008-2018 & 411 & \\
\hline 5 & CFSR Station & 44.04000 & 36.19500 & 1980-1991 & 414 & \\
\hline 6 & Erbil Meteorological Station & 44.03890 & 36.19500 & 1992-2018 & 420 & \\
\hline 7 & Ankawa Station & 44.01190 & 36.22060 & \multirow{10}{*}{$2001-2006$} & 434 & \\
\hline 8 & Rawandoz Station & 44.53390 & 36.61690 & & 677 & \\
\hline 9 & Soran Station & 44.54280 & 36.65810 & & 679 & \\
\hline 10 & Khalifan Station & 44.40060 & 36.60390 & & 687 & \\
\hline 11 & Harir Station & 44.35500 & 36.54750 & & 724 & \\
\hline 12 & Shaqlawa Station & 44.32140 & 36.40560 & & 975 & \\
\hline 13 & Sidakan Station & 44.67110 & 36.79830 & & 1020 & \\
\hline 14 & Salahaddin Station & 44.20860 & 36.37810 & & 1087 & \\
\hline 15 & Choman Station & 44.88080 & 36.62780 & & 1090 & \\
\hline 16 & Mergasor Station & 44.30080 & 36.84000 & & 1204 & \\
\hline
\end{tabular}


trict station recorded $79 \mathrm{~mm}$ on November 21, 1992 as the highest record in that period. However, in the first decade of the twenty-first century, the fluctuation suddenly changed to an increase to the extent that on February 2, 2006 the amount of $102.3 \mathrm{~mm}$ was recorded. This value was the highest within the aforementioned period, and it should therefore be taken into consideration in the design of hydraulic structures and sew- er systems. All annual maxima of daily rainfall from 1980-2018 are presented in Table 2.

Annual rainfall in the Centre district of Erbil Province changed over time, as is shown in Figure 3. The general pattern was a decline (albeit with some fluctuation) from 1980 to 2017, yet in 2018 the amount soared to achieve $721.30 \mathrm{~mm}$. Such a value had not been recorded in Erbil meteorological sta-

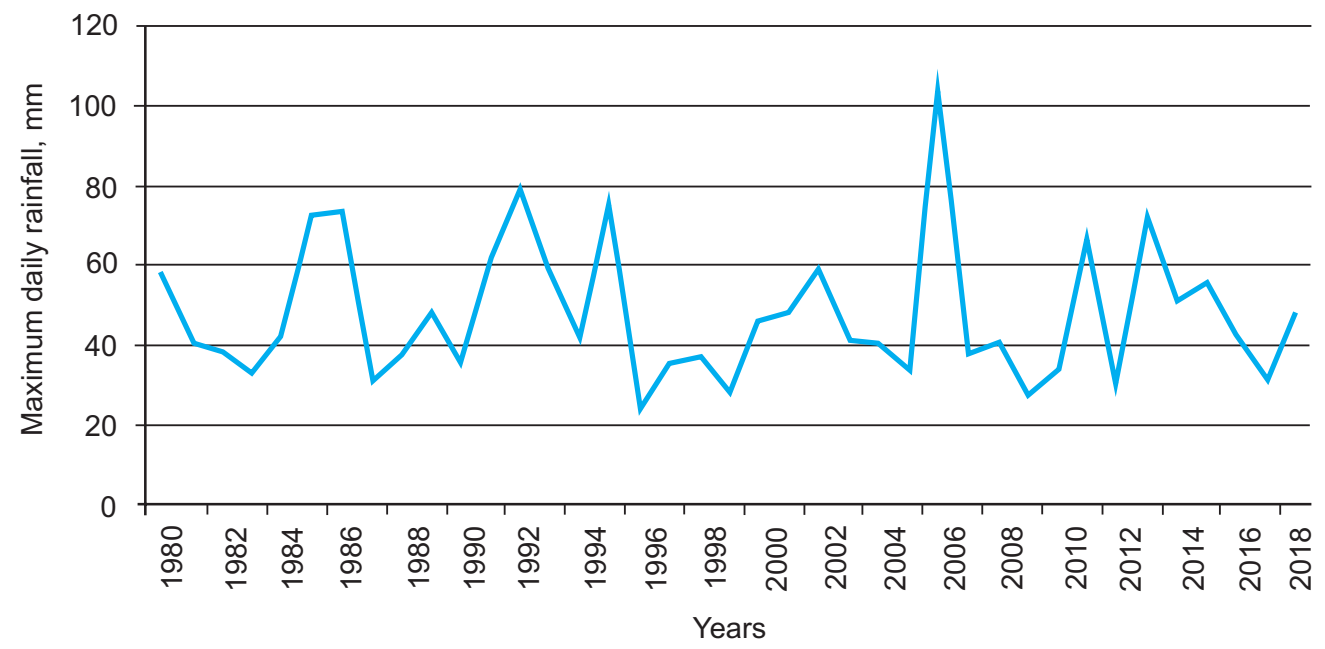

Fig. 2. Maximum daily rainfall was measured in two different stations: CFSR from 1980 to 1991, then Erbil meteorological station from 1992 to 2018

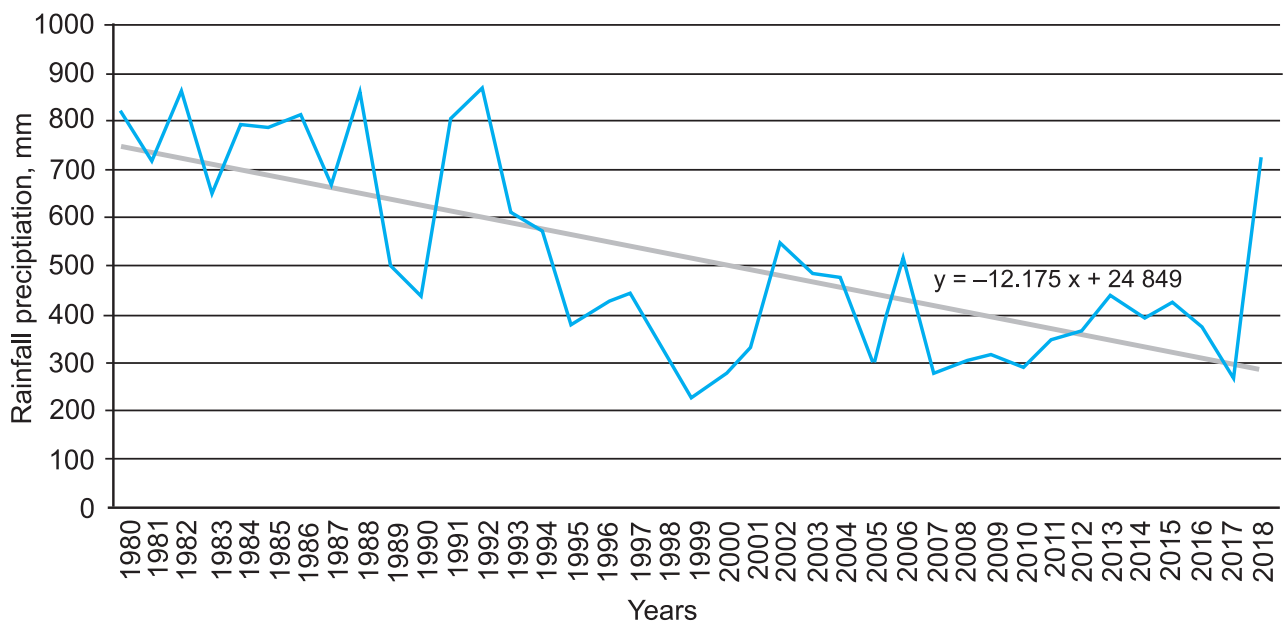

Fig. 3. Annual rainfall in the studied area was measured in two different stations: CFSR from 1980 to 1991 , then Erbil meteorological station from 1992 to 2018 
Table 2. Maximum annual daily rainfall in 1980-2018

\begin{tabular}{|c|c|c|c|c|}
\hline No. & Year & Date & $\begin{array}{l}\text { Max. daily } \\
\text { rainfall } \\
(\mathrm{mm})\end{array}$ & $\begin{array}{l}\text { Source } \\
\text { of data }\end{array}$ \\
\hline 1 & 1980 & 3 Apr. & 57.6 & \multirow{12}{*}{ CFSR } \\
\hline 2 & 1981 & 5 Nov. & 40.9 & \\
\hline 3 & 1982 & 27 Apr. & 38.1 & \\
\hline 4 & 1983 & 23 Apr. & 32.9 & \\
\hline 5 & 1984 & 18 Oct. & 42.7 & \\
\hline 6 & 1985 & 19 Mar. & 72.7 & \\
\hline 7 & 1986 & 22 Oct. & 73.6 & \\
\hline 8 & 1987 & 23 Oct. & 31.8 & \\
\hline 9 & 1988 & 8 Mar. & 37.2 & \\
\hline 10 & 1989 & 11 Nov. & 48.4 & \\
\hline 11 & 1990 & 4 Jan. & 35.8 & \\
\hline 12 & 1991 & 23 Mar. & 62.4 & \\
\hline 13 & 1992 & 21 Nov. & 79 & \multirow{27}{*}{$\begin{array}{l}\text { Erbil } \\
\text { Meteorological } \\
\text { Station }\end{array}$} \\
\hline 14 & 1993 & 7 Apr. & 57.9 & \\
\hline 15 & 1994 & 11 Mar. & 41.7 & \\
\hline 16 & 1995 & 4 Feb. & 75.7 & \\
\hline 17 & 1996 & 8 Dec. & 23.9 & \\
\hline 18 & 1997 & 15 Jan. & 35.8 & \\
\hline 19 & 1998 & 11 Jan. & 36.8 & \\
\hline 20 & 1999 & 15 Dec. & 28.3 & \\
\hline 21 & 2000 & 6 Jan. & 46.4 & \\
\hline 22 & 2001 & 8 Mar. & 48.3 & \\
\hline 23 & 2002 & 20 Dec. & 59.2 & \\
\hline 24 & 2003 & 15 Dec. & 41.4 & \\
\hline 25 & 2004 & 12 Jan. & 40.6 & \\
\hline 26 & 2005 & 4 Mar. & 34 & \\
\hline 27 & 2006 & 3 Feb. & 103.9 & \\
\hline 28 & 2007 & 3 Feb. & 38 & \\
\hline 29 & 2008 & 24 Oct. & 41 & \\
\hline 30 & 2009 & 30 Dec. & 28.2 & \\
\hline 31 & 2010 & 28 Feb. & 33.8 & \\
\hline 32 & 2011 & 22 Apr. & 67 & \\
\hline 33 & 2012 & 20. Dec. & 29.4 & \\
\hline 34 & 2013 & 28 Jan. & 71.8 & \\
\hline 35 & 2014 & 27 Jan. & 51 & \\
\hline 36 & 2015 & 31 Dec. & 55.8 & \\
\hline 37 & 2016 & 28 Mar. & 42.4 & \\
\hline 38 & 2017 & 27 Jan. & 31.4 & \\
\hline 39 & 2018 & 22 Nov. & 47.7 & \\
\hline
\end{tabular}

tion in the previous 24 years. Moreover, the maximum daily rainfall was not related to the annual rainfall. For example, the maximum annual rainfall in series was recorded in 1992, while the maximum daily rainfall in that year was $79 \mathrm{~mm}$. However, as a rule, maximum daily rainfall led to an increase in annual precipitation, which was noticeable in 2006 the year that had the highest maximum daily rainfall in 38 years.

\section{Spatial distribution of rainfall}

The terrain and topography of the area have a significant impact on the spatial distribution of precipitation, due to air temperature. At high altitudes, the probability of precipitation is high compared to low altitudes. Figure 4 presents the geomorphology of Erbil Province, showing that in the north and northeast of Erbil, the elevation above sea level (ASL) is high. In some places, it reaches $3000 \mathrm{~m}$ on average, and the altitude decreases in the Centre district by about $2500 \mathrm{~m}$. As a result, the amount of precipitation also decreases. Accordingly, the amount and type of precipitation in the Centre district of Erbil differs from other neighbourhoods.

Figure 5 shows the relationship between the amount of mean annual rainfall in 2001-2006 and the elevation ASL in Erbil Province. The Mergasur district, which is $158 \mathrm{~km}$ away from the Centre district, has yearly precipitation of $1307.9 \mathrm{~mm}$ and is situated at an altitude of $1204 \mathrm{~m}$ ASL. Rawanduz, located at $677 \mathrm{~m} \mathrm{ASL}$, has an annual rainfall of $783.8 \mathrm{~mm}$. Southern part of the Centre district, Qushtapa sub-district, which is only $23 \mathrm{~km}$ away, has a total of $398 \mathrm{~mm}$ of rainfall per year. The overall line graph showed, however, that as the altitude rises, and outside the Centre district to the north and northeast, the amount of annual rainfall increases.

\section{Temporal rainfall distribution}

Because an hourly precipitation dataset was only available for Erbil Centre district from 2008 onwards, i.e. for the years 2008-2018, the following maximum daily episodes were investigated;

- The measured rainfall on April 22, 2011 covered all Erbil Province. However, the amount of rainfall was different between stations; for example, in Mergursur district, which is a mountaino- 


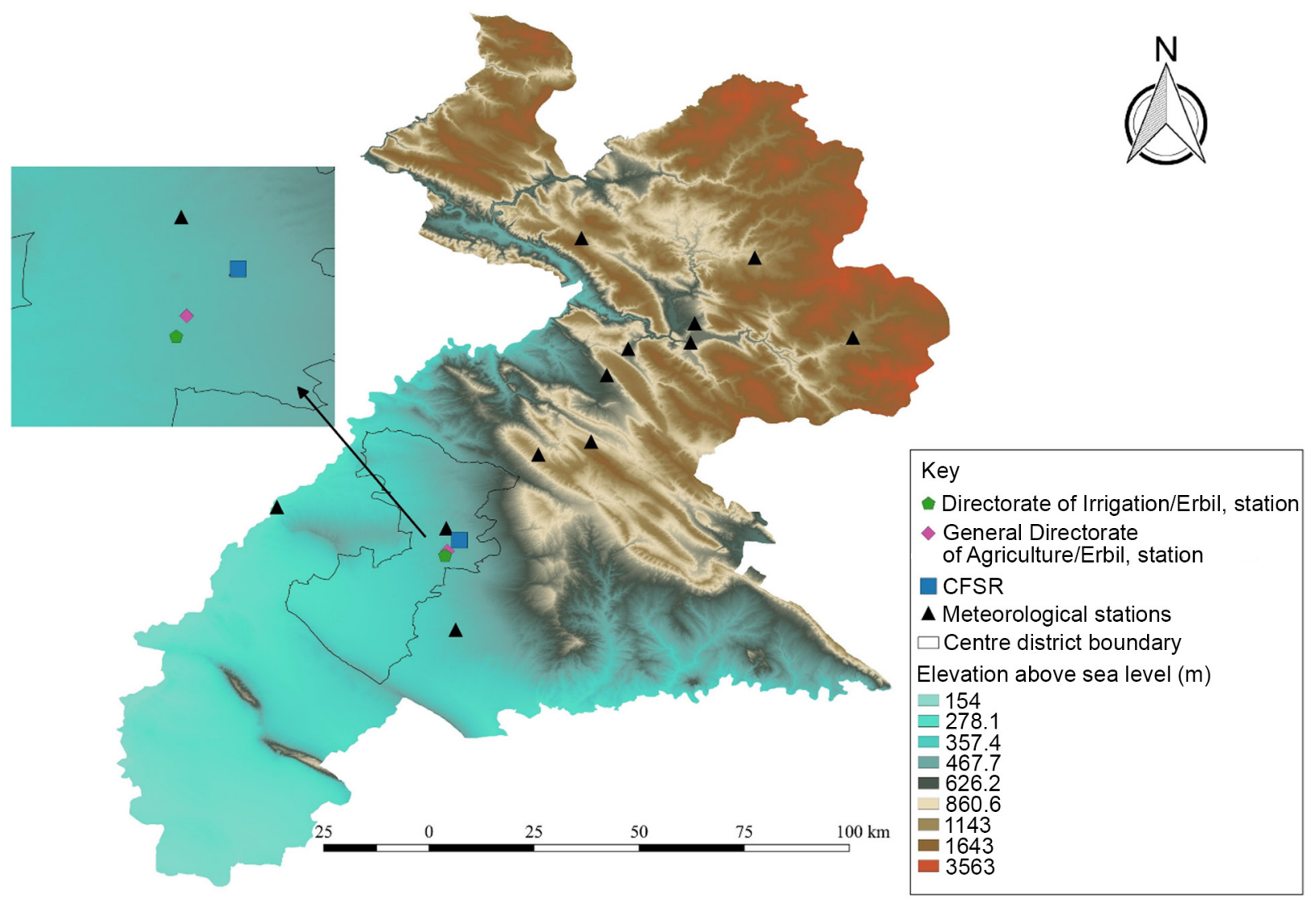

Fig. 4. Erbil topography and the location of meteorological stations

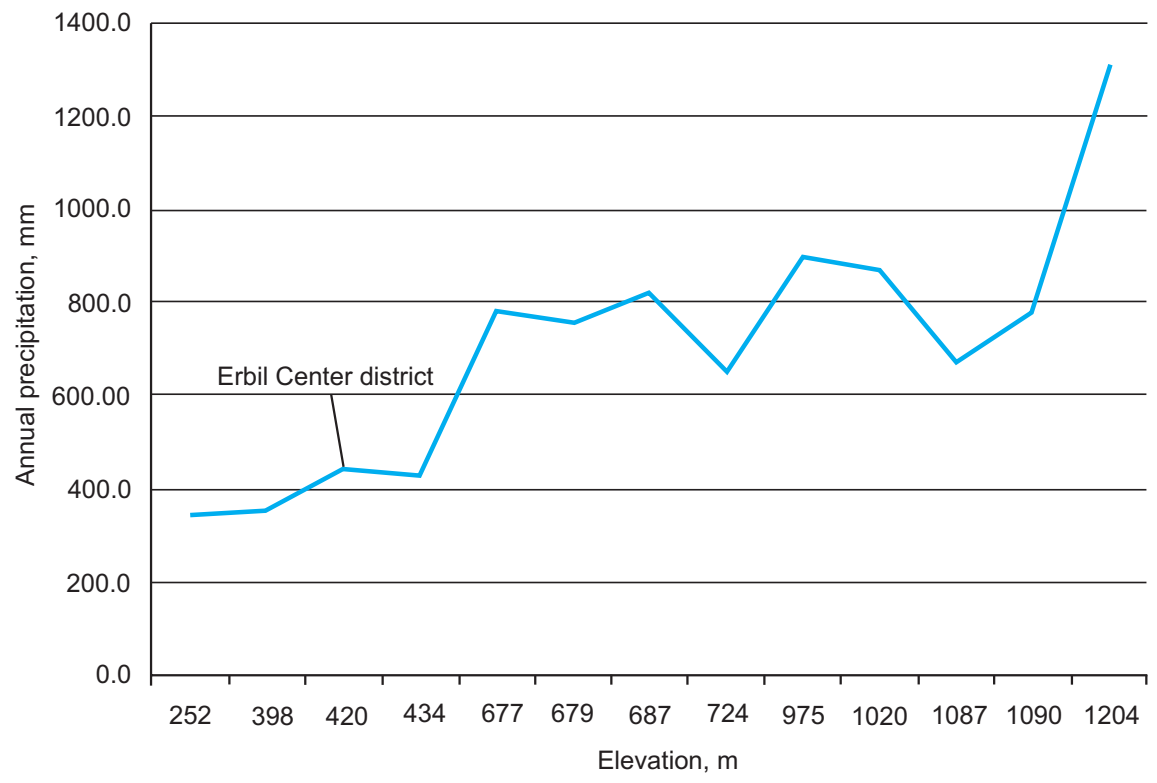

Fig. 5. The relationship between annual precipitation and elevation ASL in Erbil Province 
us area, situated at an altitude of $1204 \mathrm{~m} \mathrm{ASL}$, the amount of $96.2 \mathrm{~mm}$ was recorded, also in the south of Erbil, which is more or less flat terrain, in Qushtapa sub-district, the amount of $22.3 \mathrm{~mm}$ was recorded at an altitude of $398 \mathrm{~m} \mathrm{ASL}$. In the Centre district, according to Erbil meteorological station, $67 \mathrm{~mm}$ of rainfall was recorded. According to the automatic station of Erbil Directorate of Irrigation, located in the Centre of Erbil, this episode began at 2:00 am and ended at 10:00 pm with a total of $48.9 \mathrm{~mm}$, with the main part of the rainfall between $6: 00 \mathrm{pm}$ and $10: 00 \mathrm{pm}$, as shown in Figure 6a.

- The episode of January 28, 2013, was the highest amount of rainfall recorded in the second decade of the twenty-first century by Erbil meteorological station, at $71.8 \mathrm{~mm}$. It lasted for 27 hours, according to Erbil Directorate of Irrigation station; the first phase of the event started at 2:00 am until 6:00 am, then stopped for about 10 hours and began again at 4:00 pm till 0:00 am the next day (January 29, 2013). Moreover, the last phase of this episode started after just one hour, at 2:00 am, and the majority of rainfall was recorded by $2: 00 \mathrm{pm}$; consequently, $69.5 \mathrm{~mm}$ was recorded in this station, as shown in Figure 6b. Between January 27 and 29, 2013, all of the stations in Erbil Province recorded extreme events, for instance, $362.2 \mathrm{~mm}$ in three days in the mountainous area of Mergasur district, and at the same time in Qushtapa sub-district, the amount of $45.8 \mathrm{~mm}$ was recorded on January 28, 2013.

- On January 28, 2014, Erbil meteorological station recorded $51 \mathrm{~mm}$, and at the same time Erbil Directorate of Irrigation station recorded $44.3 \mathrm{~mm}$ of precipitation. The episode was divided into two parts; in the first and most significant part, $41.9 \mathrm{~mm}$ fell in 13 hours from 1:00 am to 1:00 pm. In the second part of the event, after 5 hours, the rain started again, and within just one hour, $2.4 \mathrm{~mm}$ was observed, as shown in Figure 6c.

- The last day of 2015 and the first day of 2016 were rainy days in Erbil Province, with a sufficient amount of rainfall; officials in Erbil meteorological station in the Centre district recorded $55.8 \mathrm{~mm}$ in 15 hours. According to the Erbil Directorate of Irrigation station, the episode started at noon on December 31, and continued till 2:00 am on January 1, 2016, as shown in Figure 6d.

- The intermittent episode of March 28, 2016, was recorded as a series of intensive rainfalls, for example, at 06:00 pm $12.2 \mathrm{~mm}$ was observed within one hour, and then at 10:00 pm $8.3 \mathrm{~mm}$ was recorded in one hour, but the total amount of $42.2 \mathrm{~mm}$ was recorded in Erbil meteorological station, as shown in Figure 6e.

- The last event occurred on November 22 and 23, 2018, when Erbil meteorological station recorded $47.7 \mathrm{~mm}$ of rainfall in 10 hours. According to Erbil Directorate of Irrigation station, the episode started late at night at $11: 00 \mathrm{pm}$ and it continued till 8:00 am on November 23, 2018, as shown in Figure 6f.

Huff (1967) suggested a group of dimensionless, synthetic rainfall time distribution patterns, which were formulated based on a set of data from watersheds in the mid-western USA. The derived correlations are practicable to the Midwest in the USA and other regions of the world with similar climate and topography. The episodes were categorised into four quartiles in which the peak rainfall intensity occurs in the first, second, third or fourth group of the storm duration, as shown in Figure 7. Within each group, the distribution was plotted for various probabilities of occurrence. The broad interpretation of the groups is presented by the first quartile; half the total depth is observed in the first $25 \%$ of the storm duration. In the second quartile, half the depth is between 25 and $50 \%$ of the total time. In the third quartile, half the total depth occurs between 50 and $75 \%$ of the rainfall duration. In the fourth quartile, half the total depth is observed between 75 and $100 \%$ of the total rainfall duration. Various studies have concentrated on utilising Huff curves in temporal rainfall distributions in different parts of the world. Nascimento et al. (2012) modelled the time distribution of rainfall using a dimensionless hyetograph in a similar way to the Huff quartiles. Moreover, Bezak et al. (2018) studied the impact of duration and temporal rainfall distribution on hydraulic flood modelling results in the Glinscica stream catchment in Slovenia using the Huff curves. In this study, those quartiles and curves are used as a rainfall time distribution classification, 
Mustafa, A.M., Muhammed, H.H., Szydłowski, M. (2019). Extreme rainfalls as a cause of urban flash floods; a case study of the Erbil-Kurdistan region of Iraq. Acta Sci. Pol., Formatio Circumiectus, 18 (3), 113-132. DOI: http://dx.doi.org/10.15576/ASP.FC/2019.18.3.113

22.04.2011

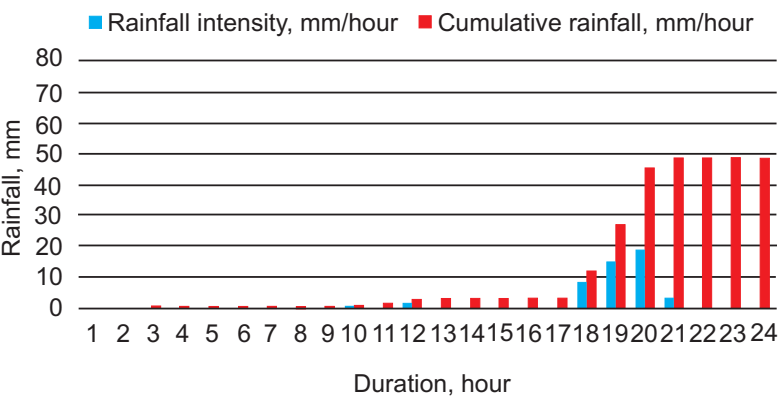

(a)

28.01.2014

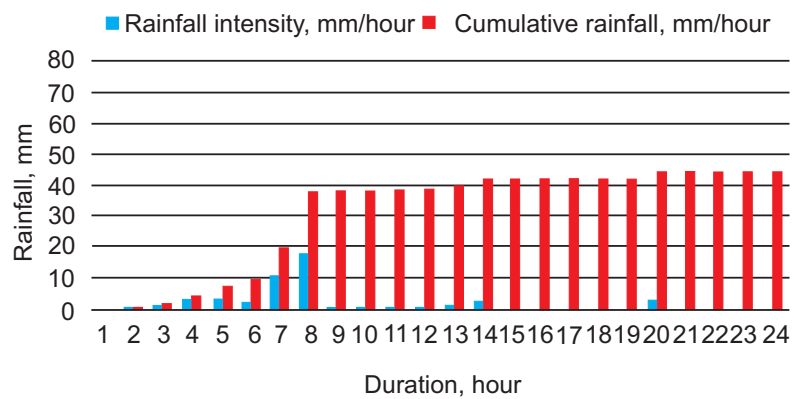

(c)

28.03.2016

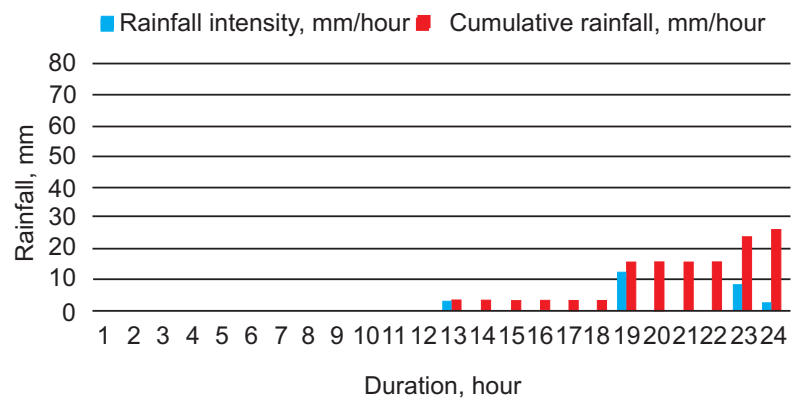

(e)
28.01.2013-29.01.2013

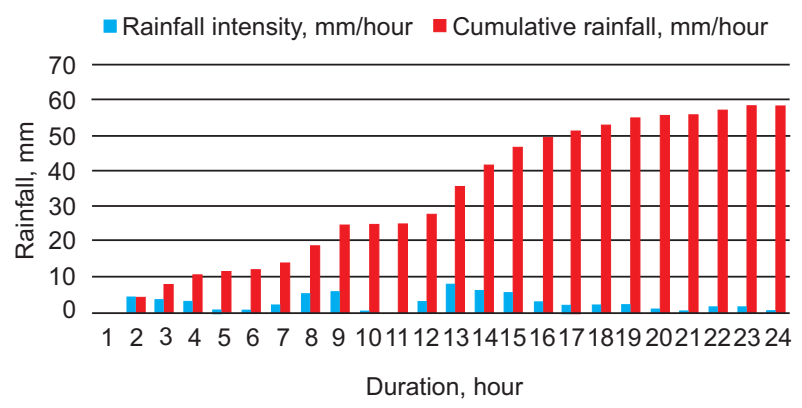

(b)

31.12.2015-01.01.2016

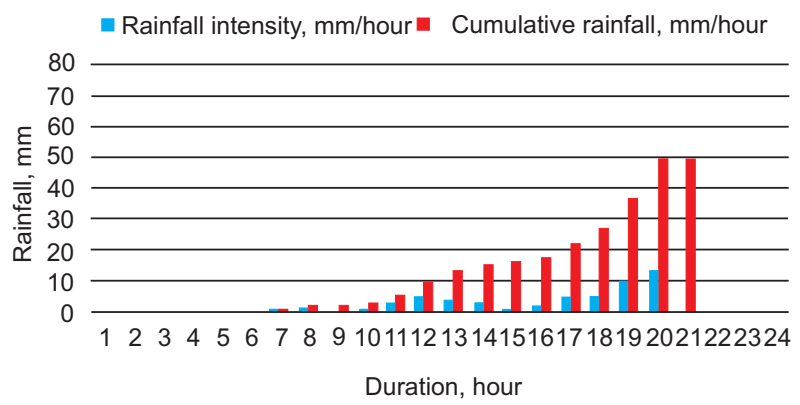

(d)

22.11.2018-23.11.2018

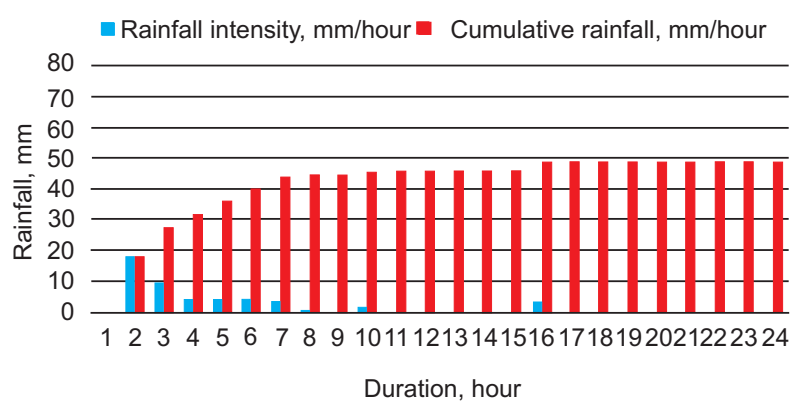

(f)

Fig. 6. Temporal rainfall distribution, measured in the automated meteorological station of the directorate of Irrigation/Erbil (a) Temporal rainfall distribution of 22.04.2011. (b) Temporal rainfall distribution of 28.01.2013-29-01.2013. (c) Temporal rainfall distribution of 28.01.2014. (d) Temporal rainfall distribution of 31.12.2015-01.01.2016. (e) Temporal rainfall distribution of 28.03.2016. (f) Temporal rainfall distribution of 22.11.2018-23.11.2018 


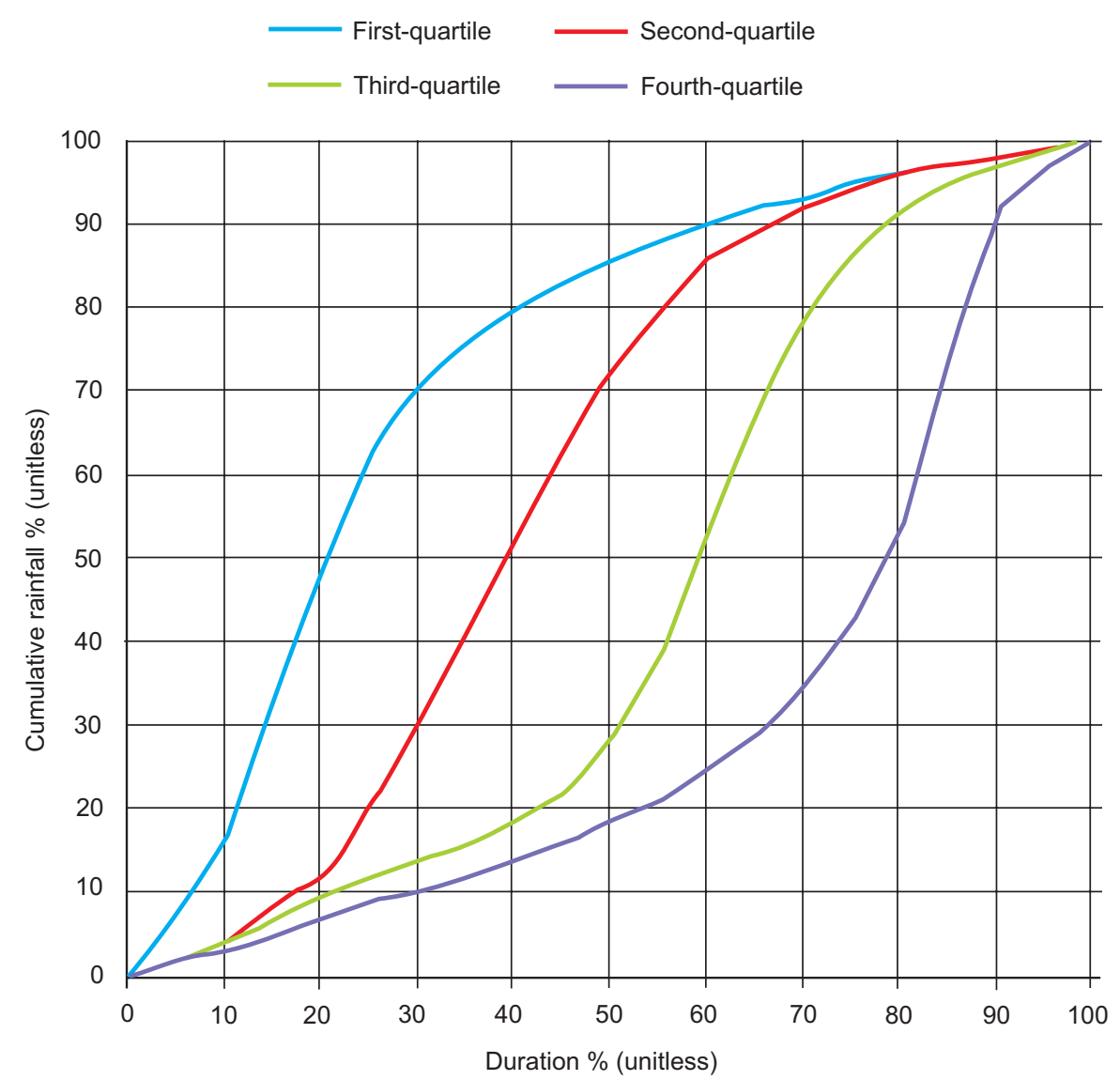

Fig. 7. Storm-quartile classifications by Huff, 1967

for comparison with the temporal rainfall distribution of some extreme rainfall episodes in the studied area. The reason that Huff quartiles and curves are utilised for the studied area is that there exist no synthetic rainfall time distributions or studies focusing on this subject.

Rainfall intensity varies widely from site to site. Because there has been no research in the studied area focusing on the analysis of rainfall and its characteristics, Intensity-Duration-Frequency IDF curves have also not been created nor are they available. For this reason, the rainfall events that are mentioned above will be compared to an American scale, which was formulated by the American Meteorology Society (AMS) (Glickman 2000) (glossary of meteorology), in which the intensity of rainfall was subdivided into four groups, as shown in Table 3.
Table 3. Classification of rainfall intensity, according to the AMS

\begin{tabular}{cc}
\hline Type of Rainfall intensity & Amount in one hour (mm) \\
\hline Light rain & $<2.5$ \\
\hline Moderate rain & $>2.5$ and $<7.6$ or 10 \\
\hline Heavy rain & $>7.6$ or between 10 and 50 \\
\hline Violent rain & $>50$
\end{tabular}

\section{Exceedance probability}

The analysis of the dataset for the past 38-year-period has been conducted. During the analysis, it was observed that the maximum daily rainfall occurred in the first decade of the twenty-first century, in 2006. Also, out of the nine largest episodes between 1980 and 2018, four of them happened in this century, and equalled $44 \%$ of the 
total during this period, whereas the remaining amount occurred in the previous century with total daily rainfall not exceeding $79 \mathrm{~mm}$ (see: Table 4). Thus, rainfall on February 3, 2006, was characterised by the maximum totals in the history of Erbil meteorological station after the establishment of Kurdistan regional government in 1992, also since the Iraq-Iran war (1980-1988).

Table 4. Comparison of maximum daily rainfall episodes: at the end of the 20th century, and at the beginning of the 21st century, recorded at Erbil meteorological station and CFSR- in 1980-2018

\begin{tabular}{ccc}
\hline $\begin{array}{c}\text { 20th century: } \\
\mathbf{1 9 8 0}-\mathbf{2 0 0 0} \\
\text { (21 years) }\end{array}$ & $\begin{array}{c}\text { The occurrence of } \\
\text { rainfall episodes } \\
\text { with the largest } \\
\text { annual daily } \\
\text { precipitation }\end{array}$ & $\begin{array}{c}\text { 21st century: } \\
\mathbf{2 0 0 1 - 2 0 1 8} \\
\text { (18 years) }\end{array}$ \\
\hline $\begin{array}{c}\text { 1992-79 mm } \\
1995-75.7 \mathrm{~mm}\end{array}$ & $\begin{array}{c}\text { The three largest } \\
\text { episodes }\end{array}$ & $2006-103.9 \mathrm{~mm}$ \\
\hline $1992-79 \mathrm{~mm}$ & & \\
$1995-75.7 \mathrm{~mm}$ & $\begin{array}{c}\text { The six largest } \\
\text { episodes }\end{array}$ & $2006-103.9 \mathrm{~mm}$ \\
$1986-73.6 \mathrm{~mm}$ & & \\
$1985-72.7 \mathrm{~mm}$ & & $2006-103.9 \mathrm{~mm}$ \\
\hline $1992-79 \mathrm{~mm}$ & & $2013-71.8 \mathrm{~mm}$ \\
$1995-75.7 \mathrm{~mm}$ & The nine largest \\
$1986-73.6 \mathrm{~mm}$ & episodes & $2011-67 \mathrm{~mm}$ \\
$1985-72.7 \mathrm{~mm}$ & & $2002-59.2 \mathrm{~mm}$ \\
$1991-62.4 \mathrm{~mm}$ & & \\
\hline
\end{tabular}

In the first stage, the sequences were ranked from the most significant episode to the smallest, then the empirical exceedance probability was calculated for the dataset from 1980-2018, according to the Weibull equation (Weibull 1951):

$$
p(i)=\frac{r}{N+1}
$$

where $p$ is the exceedance probability, $r$ represents the location of a specific episode in the rainfall distribution series, and $N$ is the size of the series.

Lognormal distribution, as a statistical model of the precipitation probability distribution function, was applied. Parameters were estimated using the maximum likelihood method, i.e. the approach used by the Polish Hydrologists Association (Banasik et al., 2017). Generally, there are two approaches in order to obtain the final results of IDF formulas: empirical and theoretical. In the second approach, theoretical distribution functions are applied, and the parameters are calculated depending on the statistical approach. K. Weinerowska-Bords (2015) determined the practical problems related to the formulation of IDF curves and formulas (for example, homogeneity and independence of the sample, and storm episode selection for the development of the Gdańsk IDF-formula using the controlled random search method). Koutsoyiannis (1998) worked on several appropriate distribution functions to develop a general formula for the rainfall intensity-duration-frequency IDF relationship; Lognormal distribution was one of the distribution functions that was used in the study (Ben-Zvi, 2009).

The values of $P_{\max , p}$ indicating the maximum daily annual rainfall with a given probability of an excess of $p$ were calculated using the following equation:

$$
P_{\max , p}=\in+\exp \left(\mu+\sigma \cdot u_{p}\right)
$$

where the lowest amount of maximum daily rainfall is denoted by $\in$; whereas $\mu, \sigma$ indicate the distribution criteria determined using the maximum likelihood estimation;

Where $\in$ can be calculated based on the below equation (Stedinger et al. 1993):

$$
\in=\frac{P_{\max (1)} P_{\max (N)}-\left(\text { median }_{i=1,2, \ldots, N}\left(P_{\max , i}\right)\right)^{2}}{P_{\max (1)}+P_{\max (N)}-2 \text { median }_{i=1,2, \ldots, N}\left(P_{\max , i}\right)}
$$

Where $P_{\max (1)} P_{\max (N)}$ are maximum and minimum values of $P_{\max , i}$ in the precipitation time series $i=1$, $2, \ldots, N$

$\mu$ - distribution parameter calculated using the method of maximum likelihood, from the formula:

$$
\mu=\frac{1}{N} \sum_{i=1}^{N} \ln \left(P_{\max , i}-\epsilon\right)
$$

$\sigma$ - distribution parameter calculated using the method of maximum likelihood, from the formula:

$$
\sigma=\sqrt{\frac{1}{N-1} \sum_{i=1}^{N}\left[\ln \left(P_{\max , i}-\epsilon\right)-\mu\right]^{2}}
$$

And $u_{p}$ is the quantile of the $p$ order in standardized normal distribution. 
For the series of data, the hypothesis was verified using the Kolmogorov test. The $p_{\text {value }}$ of the test was 0.92 , and there were no grounds for rejecting the hypothesis that the distribution of maximum rainfall is a lognormal distribution.

\section{RESULTS}

The first set of analyses investigated the time distribution and intensity of each event. The first episode, which was on April 22, 2011, continued for about 20 hours in three phases but there was a stop in between; in the first and second phase there was no significant trend to be mentioned, while the third phase, which started at 6:00 $\mathrm{pm}$, continued for five hours until 10:00 pm. In the latter phase, $90 \%$ of the rainfall was observed in $60 \%$ of the time, which was nearly the same as the second quartile of the Huff method (see: Fig. 8a). Moreover, in the third phase of the discussed episode, in the first three hours, rainfall intensity was $8.4,15.3,18.6 \mathrm{~mm}$ /hour, respectively. According to the American Meteorology Society (AMS) (glossary of meteorology), these rainfall intensities were described as heavy rainfall. In the second episode, which was on January 28 and 29, 2013, the total amount of $69.5 \mathrm{~mm}$ was recorded at the Directorate of Irrigation / Erbil station. The episode continued for 37 hours, albeit in two phases with a break-off in between. In the first phase, there was no significant point to be mentioned, while in the second phase, a total amount of $58.6 \mathrm{~mm}$ was recorded in 23 hours without any intensive rainfall during this period; intensity was between (0.1-7.6) $\mathrm{mm} /$ hour; as such, it was considered to be moderate and light rain, and only one hour exceeded this range by $0.1 \mathrm{~mm}$ and was therefore classified as heavy rain. The second phase of this episode was also nearly the same as the second quartile of the Huff method (see: Fig. 8b). The episode of January 28, 2014 , continued for 13 hours; at the beginning, the rainfall started with light intensity up to $40 \%$ of the time, then for between 40 and $60 \%$ of the total duration of the rainfall, about $90 \%$ of the total rainfall amount was observed with heavy intensity, which was also considered to be nearly the same as the second quartile of the Huff method (see: Fig. 8c). The significant point was in the middle stage of the event when the intensity reached 10.4 and $17.8 \mathrm{~mm} /$ hour, respectively, which was also considered to be heavy rainfall according to the AMS.
The episode of December 31, 2015, to January 1, 2016, was a rainfall lasting 15 hours continuously; at the beginning, rain intensity was light and moderate, then at the range of $90 \%$ of the total rainfall observed during $90 \%$ of the rainfall duration, which was the same as the fourth quartile of the Huff method (see: Fig. 8d). This episode is also regarded as heavy rainfall because nearly at the end of the episode the amounts of 9.9 and $13.1 \mathrm{~mm} /$ hour were recorded, respectively. The rainfall of March 28, 2016, was an intermittent episode, as in some hours values of 8.3 and $12.2 \mathrm{~mm} /$ hour were recorded, but not continuously. Because this episode was irregular, it was difficult to compare to any of the quartiles of the Huff method. However, the intensity of rainfall was considered to be heavy rainfall, because the two aforementioned hours within the episode surpassed the heavy rainfall range of $7.6 \mathrm{~mm} /$ hour according to the AMS. The episode of November 22-23, 2018 was different from the previously mentioned events, because this episode started immediately with heavy rains reaching an intensity of 18.2 and $9.3 \mathrm{~mm} /$ hour, respectively. In the first two hours, which was in the $30 \%$ range of total rainfall duration, $70 \%$ of cumulative rainfall was observed, and the shape of the curve was nearly the same as the first quartile of the Huff method (see: Fig. 8e).

The most important point to be made is that out of six episodes, five of them are classified as heavy rainfalls. Heavy rainfall is one of the factors affecting the occurrence of flash floods; the other factors are related to topography, urban development, sewer systems, and awareness. According to the reports by municipality officials and photos in the media in which the consequences of the previously mentioned rainfall episodes were investigated, in all events flash floods occurred for hours, and then, on the next day, the situation returned to normal.

Comparing the rainfall episodes in the studied area to the Huff quartiles revealed that out of six events, three of them were similar to the second quartile (half of the rainfall is between 25 and $50 \%$ of the total duration). Also, two of them are identical to the first and fourth quartiles, and one of the episodes could not be compared because of irregularity.

Statistical analysis was performed in the form of box plots. Box plot is a very powerful tool for understanding our data and patterns of distribution, median, 


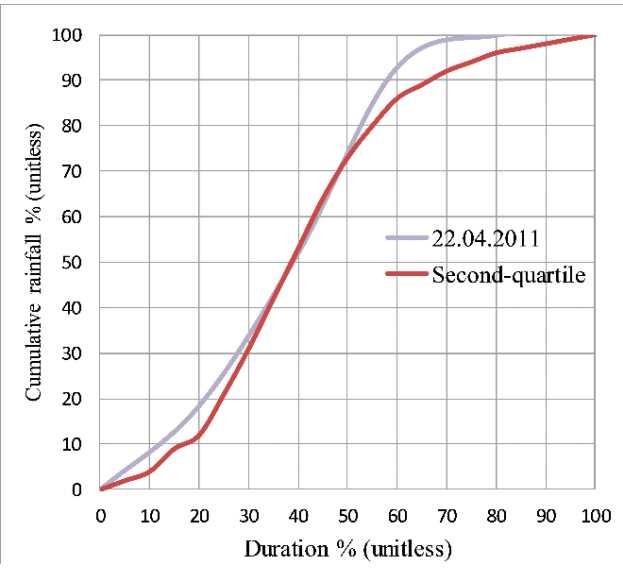

(a)

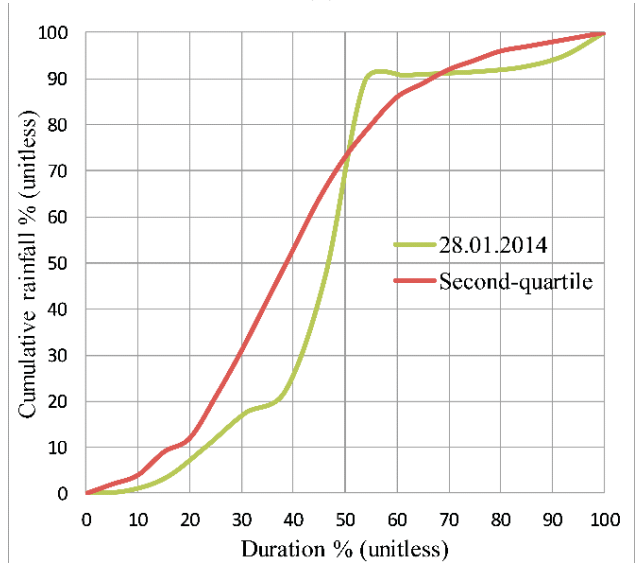

(c)

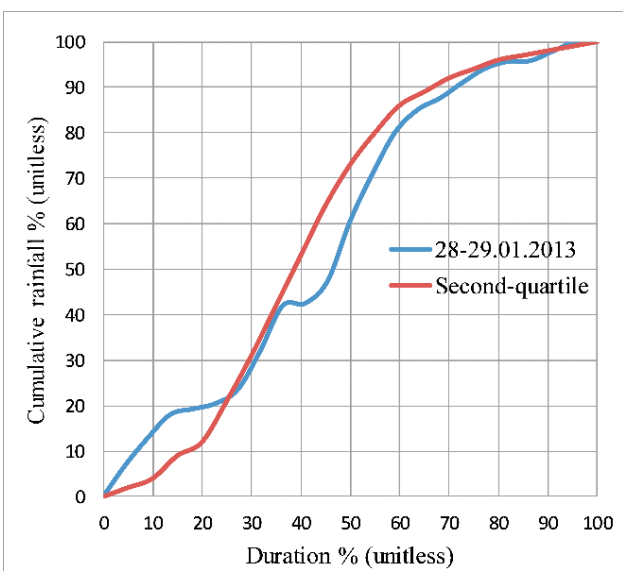

(b)

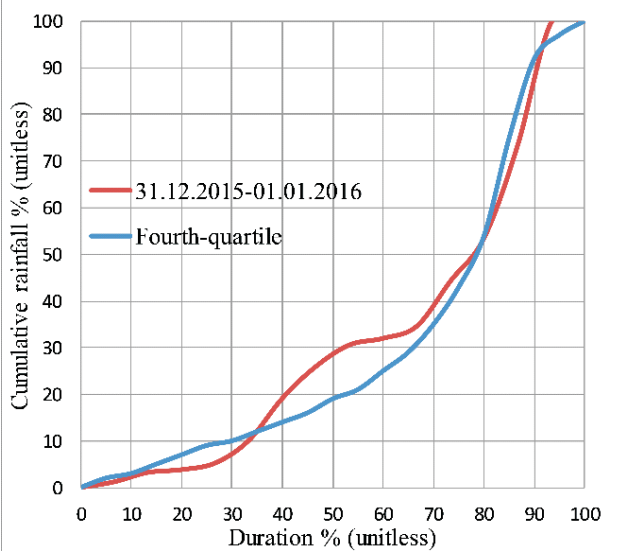

(d)

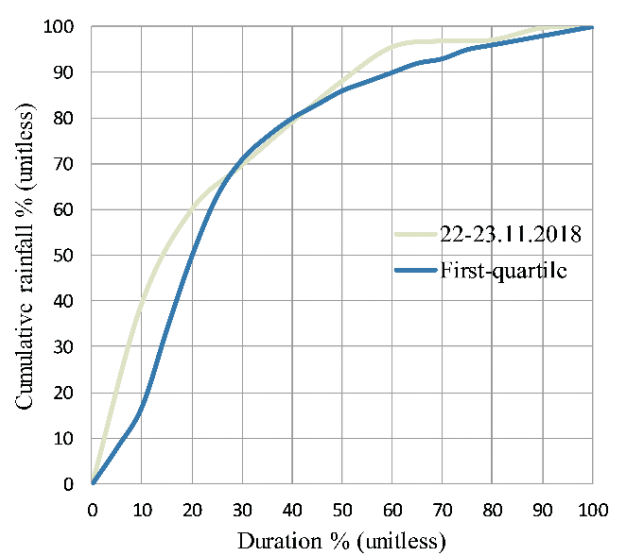

(e)

Fig. 8. Comparison of the unitless time distribution of extreme rainfall events, measured in the automated meteorological station of the directorate of Irrigation/Erbil (a) the episode of 22.04.2011 compared with the second quartile of the Huff method. (b) the episode of 28-29.01.2013 compared with the second quartile of the Huff method. (c) the episode of 28.01.2014 compared with the second quartile of the Huff method. (d) the episode of 31.12.2015-01.01.2016 compared with the fourth quartile of the Huff method. (e) the episode of 22-23.11.2018 compared with the first quartile of the Huff method 
outliers, and variance. The box plots are not all mutually symmetrical, except for the box plot of February, which is in fact comparatively symmetrical (see: Fig. 9b). However, the rainfall data were skewed positively in the months of January and March, meaning that the majority of the data fall within the lower quartile. This suggests that overall data have a high level of mutual consonance for the months of January and March. The shape of the plots enables us to visualize the similarity and variance in the data set. In spite of high data consonance, all the box plots had outlier values, which might, in turn, affect the appearance of the box plots. The descriptive statistical analysis for maximum annual precipitation showed that the maximum value is $103.9 \mathrm{~mm}$ and the minimum value is $23.9 \mathrm{~mm}$, while the mean value and standard deviation are $47.81 \mathrm{~mm}$ and $17.42 \mathrm{~mm}$, respectively. The lines in the boxes represented the median of the distribution for each month. The bounds of the boxes represented the 25th and 75th percentiles. The whiskers extended to the edges of $1.5 \times$ interquartile range, and points outside of those bounds are shown individually (see: Fig. 9a and b).

The probability distribution of daily maximum rainfall totals, based on 39-year dataset (1980-2018) sequences, is shown in Figure 10, according to log- normal distribution. Four events had an occurrence probability of between $1-10 \%$, while the occurrence probability of other events was between $10-100 \%$. The events of April 22, 2011, January 28-29, 2013, Jan-

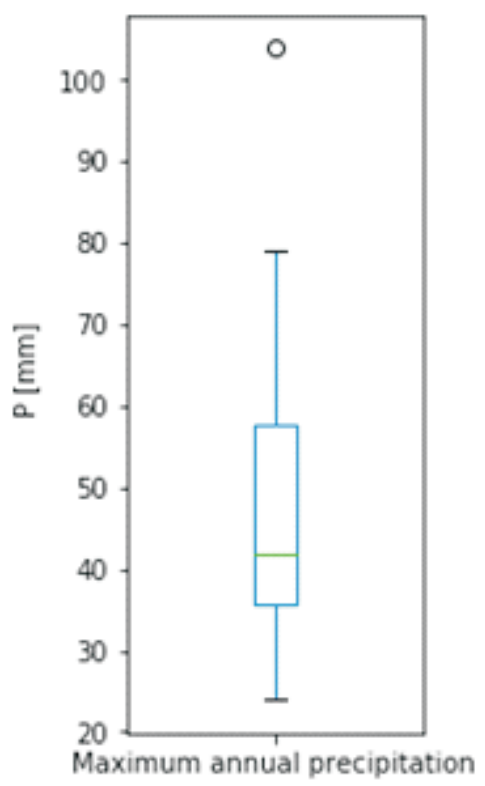

Fig. 9a. Box plot representing the distribution of maximum annual precipitation for the 39 years' data set

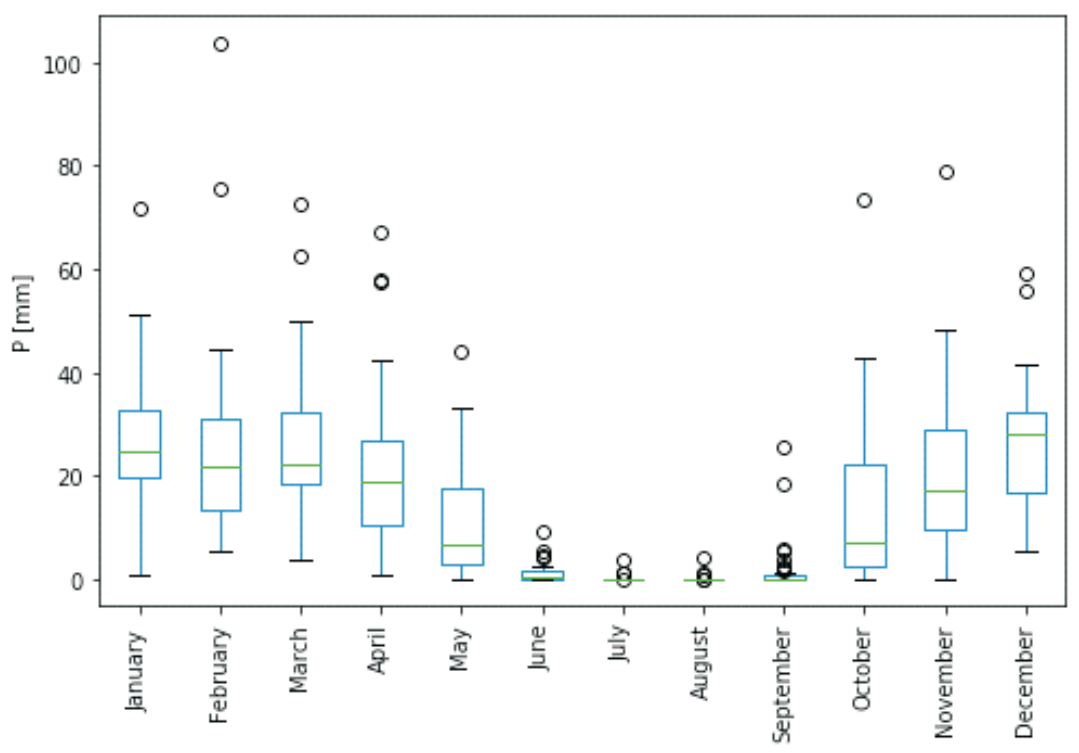

Fig. 9b. Box plot representing the distribution of maximum precipitation in each month for the 39 years' data set 


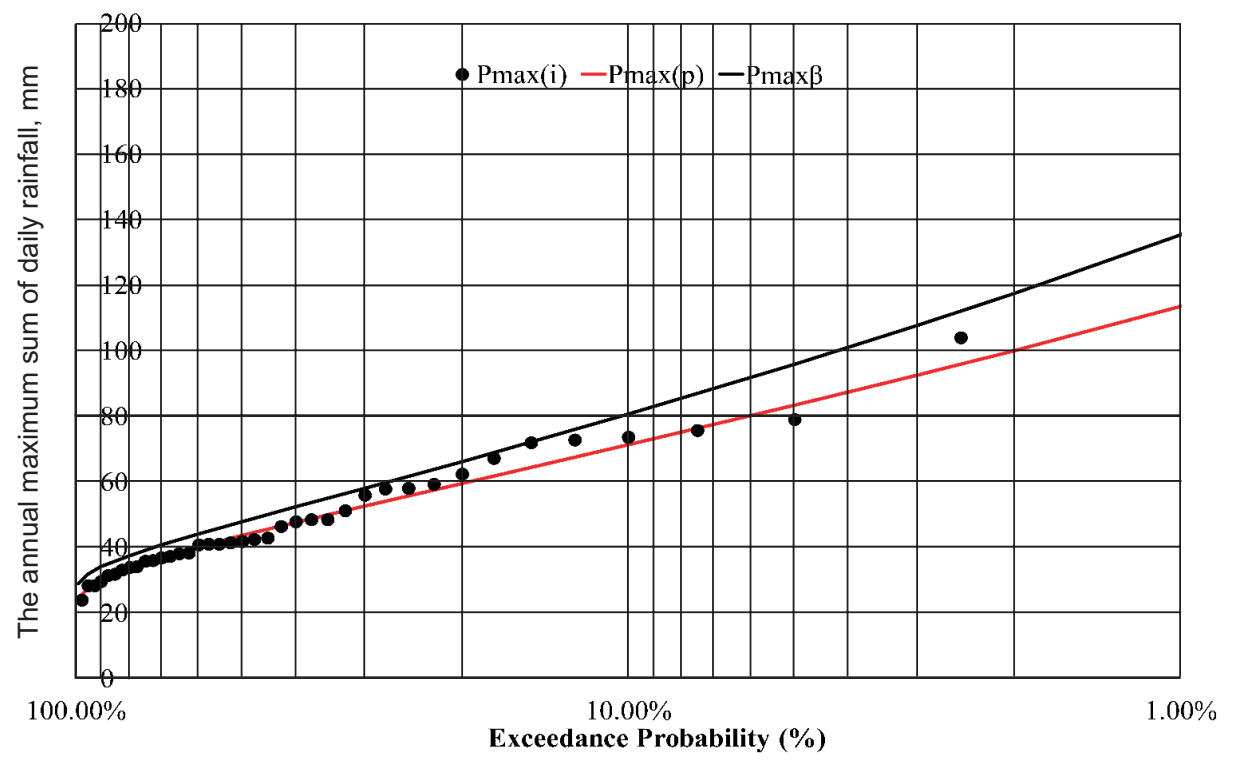

Fig. 10. The exceedance probability curve according to lognormal distribution with the maximum likelihood estimation (MLE) and the $85 \%$ confidence interval limit $-P_{\max (p) \beta}$. $P_{\max (i)}$ denoting the empirical probability of the occurrence of annual maximum daily rainfall, $P_{\max (p)}$ denoting the theoretical probability of the occurrence of annual maximum daily rainfall

uary 28, 2014, December 31, 2015-January 1, 2016, March 28, 2016, and November 22-23, 2018 had the occurrence probability of $17.5,15,32.5,30,47.5$ and $40 \%$, respectively. In the case of exceedance, the theoretical probability of $1 \%$ increase in the maximum value of the annual daily total of rainfall is small at $113.45 \mathrm{~mm}$, compared to the highest rainfall recorded between 1980 and 2018 at $103.9 \mathrm{~mm}$, which had the empirical probability of $2.5 \%$. The theoretical probability of $10 \%$ equals $71.16 \mathrm{~mm}$, which was the amount of rainfall observed in the episode of January 28, 2013. Moreover, the theoretical probability of $20 \%$ is equivalent to $59.45 \mathrm{~mm}$ of rainfall, which could be observed frequently. It is imperative that engineers and governmental authorities concerned take these calculated occurrence probabilities into consideration when designing and planning hydraulic structures.

\section{DISCUSSION}

To our knowledge, this is the first study that has investigated extreme rainfall events in Erbil Province and especially in the Centre district. As evidenced in all analysed events, flash flooding happened in some locations inside the Centre district of Erbil - for example: Setaqan neighbourhood, Saidawa neighbourhood, some locations in $30 \mathrm{~m}$ street, Glkand neighbourhood, and some of the underpasses. Mohamad Nanekely mentioned and presented some photos of these places in his study (Nanekely et al., 2016). The results of this study showed that some phases of these rainfall episodes were classified as heavy rainfalls, but there is an important point that must be explained, which is the duration of these phases. For instance, during the rainfall of November 22-23, 2018, in the first two hours, rainfall intensity reached 18.2 and $9.3 \mathrm{~mm}$ then decreased to light and moderate rainfall ranges. Thus, the occurrence of a flash flood is dependent on the duration of an intense rainfall, and does not occur when the rainfall is of a short duration. On July 9, 2001 in Gdańsk, Poland, rainfall continued for 17 hours; in the first phase rainfall intensity was more than $15 \mathrm{~mm} /$ hour continuously for four hours, then it decreased to light and moderate ranges. We believe that the duration of this intense rainfall was short, and that there are other factors causing flash floods in the studied area, for example, urban development and change in size, which result in changing the land use/land cover from pervi- 
Mustafa,A.M., Muhammed, H.H., Szydłowski, M. (2019). Extreme rainfalls as a cause of urban flash floods; a case study of the Erbil-Kurdistan region of Iraq. Acta Sci. Pol., Formatio Circumiectus, 18 (3), 113-132. DOI: http://dx.doi.org/10.15576/ASP.FC/2019.18.3.113

ous to impervious ground. Urban development has a significant effect on increasing runoff. Hassan M. Hameed (2017), in his study covering a part of the Centre district of Erbil, showed that between 1984-2014, the amount of impervious areas and barren soil went up from $5 \%$ to $35 \%$ and $1 \%$ to $31 \%$, respectively; simultaneously, farmland and vegetation declined from $64 \%$ to $32 \%$ and from $31 \%$ to $3 \%$, respectively. This showed that the percentage of impervious areas is continuously increasing. Furthermore, as a consequence of city expansion, most of the small natural streams or temporary river routes cross the city boundary. Thus, the municipality has constructed new sewer lines, which, however, are small compared to natural streams. Also, runoff produced outside the Centre district flows into the streams during rainfall because officials in the municipality have not constructed alternative routes for the flow of this kind of runoff. Another source of urban flash flooding in the studied area is that the sewer system is insufficient and old, and in some parts of the city the system is not sufficiently connected. During most of the events, overflows will happen, which is proof of the inadequacy of the sewer system, as shown in

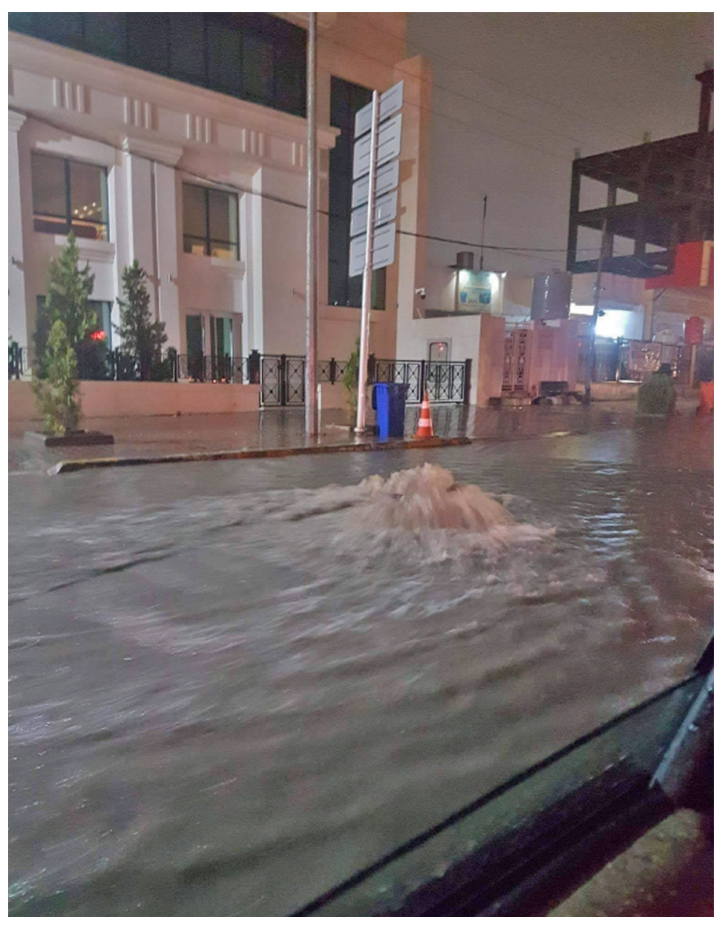

Fig. 11a. Overflow occurring in one of the man-holes on a street in Erbil

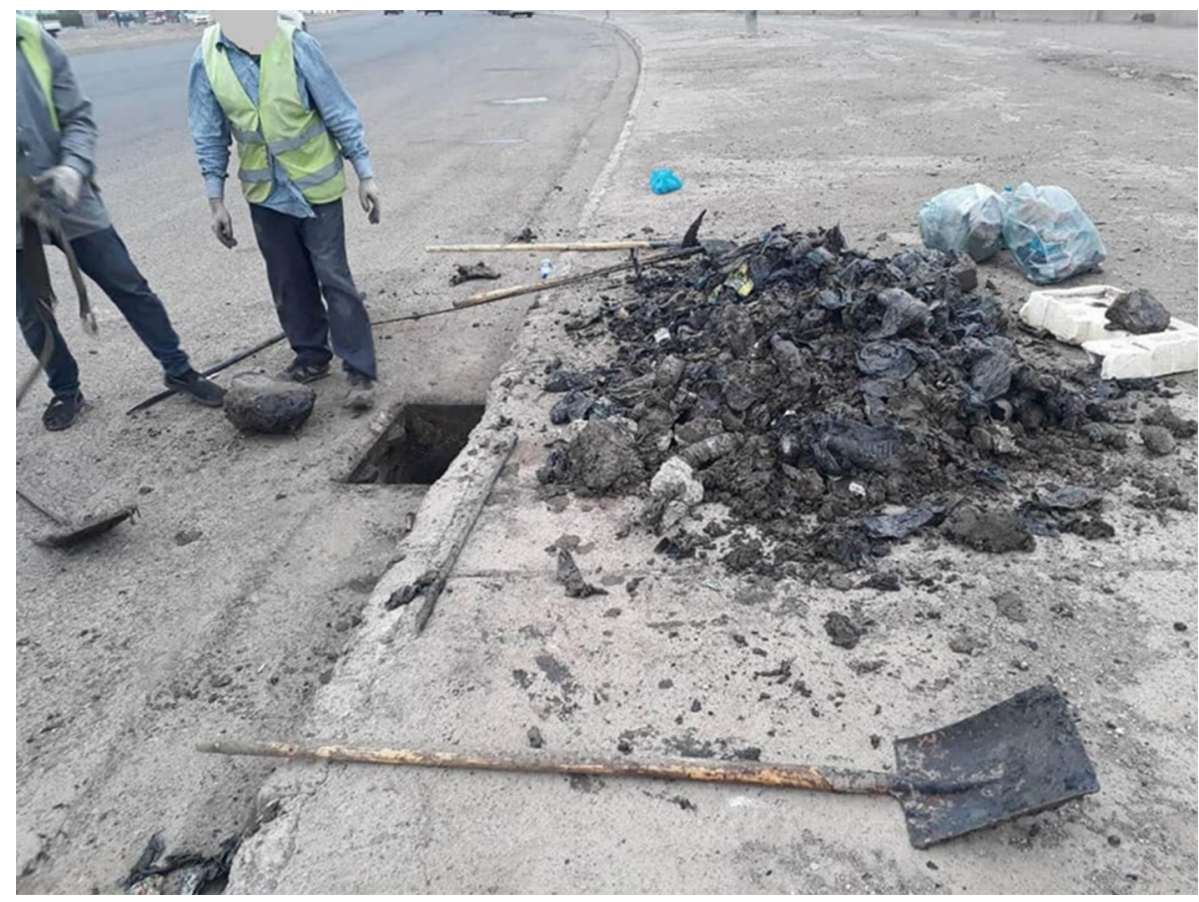

Fig. 11b. Municipality workers cleaning an inlet, which was almost completely filled with waste 
Figure 11a. Another contributing factor, related to the flaws of the sewer system within the studied area, is mismanagement of the system, and insufficient public awareness of the necessity to keep inlets, manholes and sewer lines clean - evidenced by the fact that in most flash flood events, the nodes of the sewer system under most demand did not work efficiently. Also, on the day after the event, municipality workers/specialists need to clean these focal points to allow the water to stream quickly, as shown in Figure 11b.

\section{CONCLUSIONS}

Erbil is one of the cities in Iraq, which are particularly hit by extreme rainfall events, and consequently urban flash flooding occurs in the Centre district. Erbil Centre district is characterised by flat terrain where the elevation varies between 390 and $425 \mathrm{~m}$ ASL. According to the GDMS, the amount of annual rainfall in Erbil Province ranges between $350-1300 \mathrm{~mm}$ depending on the elevation above sea level. The greatest total daily rainfall amount in the analysed 39 year-period did not exceed $103.9 \mathrm{~mm}$. Due to the fact that out of six episodes, three of them are similar to the second quartile of the Huff quartiles, the second quartile of the Huff method could be considered as the synthetic rainfall distribution in the studied area and, moreover, could be used as input data for future works in the field of hydrological modelling. Among the six analysed episodes, five of them were characterised by heavy rainfalls of a short duration. In such cases, the design criteria for the sewer system should be revised, and a new synthetic rainfall distribution must be created because in all events mentioned flash floods happened. An important conclusion resulting from the analysis of the probability of exceeding the maximum rainfall in Erbil is that the rainfalls with a probability of $1 \%, 10 \%$ or $20 \%$ are relatively high. They are $113.45 \mathrm{~mm}, 71.16$ $\mathrm{mm}$ and $59.45 \mathrm{~m}$ respectively. It should be remembered that in many cases, designers use such rainfall values in developing drainage systems. Unfortunately, in the last two decades of the twenty-first century, high rainfall returned almost every year, which is not in line with design assumptions. Nowadays, the priority should be to start incorporating these changes in design, in order to reduce the effects of floods in cities. Further analysis showed that extreme rainfall events affected cities globally, forcing them to use more and more financial resources to modify their infrastructure systems. In the case of Erbil city, no steps have been taken as yet, related to adopting a new strategy in order to stop urban flash flooding during these short, intensive rainfalls. It is essential to note the causes of flash floods in the studied area, involving not only the intensity rate and temporal rainfall distribution, but also other factors such as: topography, urban development, the sewer system, and awareness. This study is the first step in modelling the hydrological situation in the Centre district of Erbil, and the process of transforming precipitation into the outflows of urban basins will be the extension of this work in future.

\section{REFERENCES}

Allan, R. P., Soden, B. J. (2008). Atmospheric Warming and the Amplification of Precipitation Extremes. Science, 321(5895), 1481-1484.

Arnbjerg-Nielsen, K., Leonardsen, L., Madsen, H. (2015). Evaluating adaptation options for urban flooding based on new high-end emission scenario regional climate model simulations. Climate Research, 64(1), 73-84.

Ashley, R. M., Balmforth, D. J., Saul, A. J., \& Blanskby, J. D. (2005). Flooding in the future - predicting climate change, risks and responses in urban areas. Water Science and Technology, 52(5), 265-273.

Ávila, A. D., Carvajal, Y. E., Justino, F. (2015). Representative rainfall thresholds for flash floods in the Cali river watershed, Colombia. Natural Hazards and Earth System Sciences Discussions, 3(6), 4095-4119.

Banasik, K., Wałęga, A., Węglarczyk, S., Więzik, B. (2017). Aktualizacja metodyki obliczania przepływów i opadów maksymalnych o określonym prawdopodobieństwie przewyższenia dla zlewni kontrolowanych i niekontrolowanych oraz identyfikacji modeli transformacji opadu w odpływ. Warszawa: Stowarzyszenie Hydrologów Polskich.

Ben-Zvi, A. (2009). Rainfall intensity-duration-frequency relationships derived from large partial duration series. Journal of Hydrology, 367(1), 104-114.

Bezak, N., Šraj, M., Rusjan, S., Mikoš, M. (2018). Impact of the Rainfall Duration and Temporal Rainfall Distribution Defined Using the Huff Curves on the Hydraulic Flood Modelling Results. Geosciences, 8(2), 69.

Bisht, D. S., Chatterjee, C., Kalakoti, S., Upadhyay, P., Sahoo, M., \& Panda, A. (2016). Modeling urban floods and drainage using SWMM and MIKE URBAN: a case study. Natural Hazards, 84(2), 749-776. 
Christensen, J. H., Christensen, O. B. (2007). A summary of the PRUDENCE model projections of changes in European climate by the end of this century. Climatic Change, 81(1), 7-30.

Dile, Y. T., Srinivasan, R. (2014). Evaluation of CFSR climate data for hydrologic prediction in data-scarce watersheds: an application in the Blue Nile River Basin. JAWRA Journal of the American Water Resources Association, 50(5), 1226-1241.

Fuka, D. R., Walter, M. T., MacAlister, C., Degaetano, A. T., Steenhuis, T. S., Easton, Z. M. (2014). Using the Climate Forecast System Reanalysis as weather input data for watershed models. Hydrological Processes, 28(22), 5613-5623.

Glickman, T. S. (2000). Glossary of meteorology - American Meteorological Society. Boston, Mass.: American Meteorological Soc.

Hameed, H. (2013). Water harvesting in Erbil Governorate, Kurdistan region, Iraq : detection of suitable sites using geographic information system and remote sensing.

Hameed, H. M. (2017). Estimating the Effect of Urban Growth on Annual Runoff Volume Using GIS in the Erbil Sub-Basin of the Kurdistan Region of Iraq. Hydrology, 4(1), 12 .

Huff, F. A. (1967). Time distribution of rainfall in heavy storms. Water Resources Research, 3(4), 1007-1019.

Joo, J., Kjeldsen, T., Kim, H.-J., Lee, H. (2014). A comparison of two event-based flood models (ReFH-rainfall runoff model and HEC-HMS) at two Korean catchments, Bukil and Jeungpyeong. KSCE Journal of Civil Engineering, 18(1), 330-343.

Koutsoyiannis, D., Kozonis, D., Manetas, A. (1998). A mathematical framework for studying rainfall intensity-duration-frequency relationships. Journal of Hydrology, 206(1), 118-135.

KRSO. (2014). Report of the expectation of Kurdistan Region Population from 2009-2020. Retrieved from http:// www.krso.net/files/articles/130814020950.pdf

Kundzewicz, Z. W., Mata, L. J., Arnell, N. W., Doll, P., Jimenez, B., Miller, K., Shiklomanov, I. (2008). The implications of projected climate change for freshwater resources and their management. Hydrological Sciences Journal, 53(1), 3-10.

Kvočka, D., Falconer, R. A., Bray, M. (2015). Appropriate model use for predicting elevations and inundation extent for extreme flood events. Natural Hazards, 79(3), 1791-1808.

Majewski, W. C. (2016). Urban flash flood in Gdańsk 2001. Case study. Meteorology Hydrology and Water Management, 4(2), 41-49.
Miceli, R., Sotgiu, I., Settanni, M. (2008). Disaster preparedness and perception of flood risk: A study in an alpine valley in Italy. Journal of Environmental Psychology, 28(2), 164-173.

Nanekely, M., Scholz, M., Al-Faraj, F. (2016). Strategic Framework for Sustainable Management of Drainage Systems in Semi-Arid Cities: An Iraqi Case Study. Water, 8(9), 406

Nilo, de O. N., Balbi D. A. F., Naghettini M. (2012). Modeling the Time Distributions of Heavy Storms - Design Hyetographs. Building Partnerships, 1-10.

Opolot, E. (2013). Application of remote sensing and geographical information systems in flood management: a review. Research Journal of Applied Sciences Engineering and Technology, 6(10), 1884-1894.

Pall, P., Aina, T., Stone, D. A., Stott, P. A., Nozawa, T., Hilberts, A. G. J., Allen, M. R. (2011). Anthropogenic greenhouse gas contribution to flood risk in England and Wales in autumn 2000. Nature, 470(7334), 382-385.

Rojas, R., Feyen, L., Watkiss, P. (2013). Climate change and river floods in the European Union: Socio-economic consequences and the costs and benefits of adaptation. Global Environmental Change, 23(6), 1737-1751 .

Ruin, I., Lutoff, C., Boudevillain, B., Creutin, J.-D., Anquetin, S., Rojo, M. B., Vannier, O. (2013). Social and Hydrological Responses to Extreme Precipitations: An Interdisciplinary Strategy for Postflood Investigation. Weather, Climate, and Society, 6(1), 135-153.

Smith, B., Rodriguez, S. (2017). Spatial Analysis of High -Resolution Radar Rainfall and Citizen-Reported Flash Flood Data in Ultra-Urban New York City. Water, 9(10), 736.

Stedinger, J. R., Vogel, R. M., Foufoula-Georgious, E. (1993). Frequency Analysis of Extreme Events. In Handbook of Hydrology. New York: McGraw-Hill.

Szpakowski, W., Szydłowski, M. (2018). Evaluating the Catastrophic Rainfall of 14 July 2016 in the Catchment Basin of the Urbanized Strzyza Stream in Gdańsk, Poland. Polish Journal of Environmental Studies, 27(2), 861-869.

Szydłowski, M., Mikos-Studnicka, P., Zima, P., Weinerowska-Bords, K., Hakiel, J., Kalinowska, D. (2015). Stormwater and snowmelt runoff storage control and flash flood hazard forecasting in the urbanized coastal basin. 141-150.

Veldhuis, J. A. E. ten, Clemens, F. H. L. R., Gelder, P. H. A. J. M. van. (2011). Quantitative fault tree analysis for urban water infrastructure flooding. Structure and Infrastructure Engineering, 7(11), 809-821. 
Weibull, W. (1951). A Statistical Distribution Function of Wide Applicability. Journal of Applied Mechanics-Transactions of the Asme, 18(3), 293-297.

Weinerowska-Bords, K. (2015). Development of Local IDF-formula Using Controlled Random Search Method for Global Optimization. Acta Geophysica, 63(1), 232-274.
Youssef, A. M., Sefry, S. A., Pradhan, B., Alfadail, E. A. (2016). Analysis on causes of flash flood in Jeddah city (Kingdom of Saudi Arabia) of 2009 and 2011 using multi-sensor remote sensing data and GIS. Geomatics, Natural Hazards and Risk, 7(3), 1018-1042.

\section{GWAŁTOWNE OPADY DESZCZU JAKO PRZYCZYNA POWODZI W MIASTACH; STUDIUM PRZYPADKU MIASTA IRBIL W KURDYJSKIM OKRĘGU AUTONOMICZNYM W IRAKU}

\section{ABSTRAKT}

\section{Cel badań}

Badania miały na celu szczegółową ocenę i analizę niektórych ekstremalnych zdarzeń opadowych w ostatniej dekadzie - pod kątem przestrzennego i czasowego rozkładu opadów, wskaźnika intensywności i prawdopodobieństwa przewyższenia. Rozpatrujemy także wpływ każdego z analizowanych aspektów na nagłe zjawiska powodziowe występujące na badanym obszarze.

\section{Materiały i metody}

W słowniku meteorologicznym Amerykańskiego Towarzystwa Meteorologicznego (AMS) opady deszczu podzielono pod względem intensywności na cztery grupy (lekkie, umiarkowane, intensywne i gwałtowne). Ponadto do oszacowania prawdopodobieństwa przekroczenia zastosowano rozkład logarytmiczny jako model statystyczny funkcji rozkładu prawdopodobieństwa opadów.

\section{Wyniki i wnioski}

Pięć spośród sześciu analizowanych zdarzeń sklasyfikowano jako intensywne (ulewne) deszcze. Jednak czas trwania intensywnych opadów deszczu nie przekraczał dwóch godzin. Prawdopodobieństwa przewyższenia dla czterech zdarzeń maksymalnych dziennych opadów (dla 39-letniego zbioru danych) oszacowano na 1-10\%. Podsumowując, przedstawione tu badania mogą stanowić pierwszy krok do modelowania zjawisk hydrologicznych na badanym obszarze, co w przyszłości może być przydatne do kształtowania odpływów ze zlewni miejskich.

Słowa kluczowe: zmiany klimatu, powodzie miejskie, intensywność opadów, rozkład opadów w czasie, rozkład prawdopodobieństwa opadów 